\title{
Frações nitrogenadas de silagens de milho "safrinha” sob diferentes tempos de exposição ao ar antes da ensilagem
}

\author{
Nitrogenous fractions of silages from a maize crop planted late in season, under different periods of \\ air exposure previous to ensiling
}

\author{
João Pedro Velho ${ }^{\text {I* }}$ Paulo Roberto Frenzel Mühlbach ${ }^{\text {II }}$ José Laerte Nörnberg $^{\text {III }}$ \\ Teresa Cristina Moraes Genro ${ }^{\mathrm{IV}}$ Luis Maria Bonnecarrère Sanchez ${ }^{\mathrm{V}}$ \\ Ione Maria Pereira Haygert Velho ${ }^{\mathrm{I}}$ Julcemar Dias Kessler $^{\mathrm{VI}}$
}

\section{RESUMO}

Objetivou-se avaliar o efeito da maturidade dos grãos de milho e do tempo de exposição ao ar antes da ensilagem sobre o $\mathrm{pH}$ e os componentes nitrogenados de silagens de milho "safrinha". O experimento foi conduzido em delineamento completamente casualizado com arranjo fatorial $2 \times 4$, no qual foram testados dois estádios de maturidade (MA) ao corte (grão completamente leitoso (GL) ou grão $1 / 2$ leitoso $1 / 2$ farináceo (GF)) e quatro tempos de exposição ao ar (EX), sem compactação $(0,12,24$ e 36 horas) antes da ensilagem em minissilos. Houve efeito significativo $(P<0,05)$ em relação aos MA e EX, para os teores de PB e NIDN, além de interação entre esses fatores para as variáveis $\mathrm{pH}, \mathrm{N}-\mathrm{NH}_{3}$ e NIDA. Devido à interação, a silagem feita no estádio $G L$ produziu mais $\mathrm{N}-\mathrm{NH}_{3}$ do que aquelas feitas no estádio GF. A interação entre os fatores MA e EX aumentam o valor médio de $\mathrm{pH}$ das silagens produzidas, porém com diferentes magnitudes. O manejo inadequado na ensilagem decorrente da demora no enchimento do silo aumenta a fração nitrogenada insolúvel, ou seja, diminui a degradabilidade protéica, porém afeta negativamente a digestibilidade e o valor nutritivo da silagem. Silagens de milho colhidas com grão leitoso comprometem a palatabilidade pelo maior teor de nitrogênio amoniacal.

Palavras-chave: nitrogênio, $\mathrm{N}-\mathrm{NH}_{3}, \mathrm{NIDA}, \mathrm{NIDN}$, $\mathrm{pH}$, proteína bruta.

\section{ABSTRACT}

This experiment was aimed at evaluating the effect of corn grain maturity and air exposure time prior to ensiling on the $\mathrm{pH}$ and nitrogenous fractions of corn silage from corn crop planted late in the season. A completely randomized $2 \times 4$ factorial arrangement was used to test the effect of two maturity stages at harvest (GL, milky kernel and GF, 1/2 milky $1 / 2$ dough kernel) of maize crops and the effects of four periods of air exposure of chopped materials (zero, 12, 24 and 36 hours) previous to packing in mini-silos, on $\mathrm{pH}$ and $\mathrm{N}$ fractions of silages. There was a significant effect $(P<0.05)$ related to stage of maturity and period of air exposure concerning the contents of crude protein and neutral detergent insoluble nitrogen, as well as an interaction between the main effects for ammonia nitrogen and acid detergent insoluble nitrogen. Due to the interaction, the maize silage harvested at the milky kernel stage resulted in higher $\mathrm{pH}$ value and ammonia nitrogen contents. A delayed packing procedure increases the insoluble nitrogen fractions and may affect negatively protein digestibility.

Key words: nitrogen, ammonia nitrogen, ADIN, NDIN, $p H$, crude protein.

\section{INTRODUÇÃO}

A qualidade da silagem de milho pode ficar comprometida pelo excessivo tempo decorrido entre o corte da planta e o enchimento e vedação dos silos, ocasionado pela infra-estrutura inadequada, como ensiladeiras antigas e/ou sem manutenção, número e tamanho de tratores insuficientes, etc (RESENDE et al., 2005).

Portanto, mesmo a partir de uma forrageira de alta qualidade, pode-se obter forragem conservada

\footnotetext{
IPrograma de Pós-graduação em Zootecnia, Universidade Federal do Rio Grande do Sul (UFRGS), Porto Alegre, RS, Brasil. E-mail: velhojp@yahoo.com.br.*Autor para correspondência.

IIDepartamento de Zootecnia, UFRGS, Porto Alegre, RS, Brasil.

IIIDepartamento de Tecnologia e Ciência dos Alimentos, Universidade Federal de Santa Maria (UFSM), Santa Maria, RS, Brasil.

${ }^{\mathrm{IV}}$ Empresa Brasileira de Pesquisa Agropecuária (EMBRAPA), Pecuária Sul (CPPSUL), Bagé, RS, Brasil.

vepartamento de Zootecnia, UFSM, Santa Maria, RS, Brasil.

VIPrograma de Pós-graduação em Zootecnia, Universidade Federal de Pelotas (UFPel), Pelotas, RS, Brasil.
} 
de baixa qualidade se a tecnologia empregada não for adequada (JOBIM et al., 2005).

De amostras de silagens de milho coletadas de propriedades leiteiras do RS, BERTO et al. (1998) obtiveram valores médios de $33,66 \%$ de $\mathrm{MS}$, $\mathrm{pH}$ de $3,77,6,13 \%$ de $\mathrm{PB}$ na MS, $14,21 \%$ de $\mathrm{N}-\mathrm{NH}_{3}$ em $\%$ do NT e $11,73 \%$ de NIDA em \% do NT, o que indica problemas no momento da ensilagem, vedação e armazenagem e na “desensilagem”, possivelmente repercutindo no desempenho dos animais.

Os principais produtos resultantes da proteólise por ação microbiana durante a ensilagem são aminoácidos e amônia, embora algumas enzimas das plantas também degradem os aminoácidos (GIVENS \& RULQUIN, 2004; JOBIM et al., 2005). A boa preservação da silagem depende do rápido estabelecimento e manutenção da anaerobiose obtida pelo rápido enchimento do silo e a sua correta vedação (SENGER et al., 2005; SILVA et al., 2005).

Os processos que podem afetar negativamente o processo de ensilagem são: respiração, atividade enzimática da planta, atividade clostrídica no processo fermentativo e atividade microbiana aeróbia após a abertura do silo (MUCK, 1988). A respiração das plantas durante a colheita e do material picado, enquanto houver oxigênio no silo, ocasiona perdas dos carboidratos solúveis e, consequentemente, eleva as concentrações de PB, FDN, FDA, lignina e outras frações que não são afetadas pela respiração, sendo que parte da proteína verdadeira é convertida a NNP (ROTZ \& MUCK, 1994).

Neste estudo, objetivou-se avaliar o efeito da maturidade da planta de milho e o efeito do tempo de exposição ao ar antes da ensilagem sobre o pH e os componentes nitrogenados de silagens de milho "safrinha”.

\section{MATERIAL E MÉTODOS}

O trabalho de campo foi desenvolvido em uma propriedade particular no município de Palmeira das Missões, RS, com clima do tipo Cfa, subtropical, com verões quentes e chuvas bem distribuídas ao longo do ano, com temperatura média de $22^{\circ} \mathrm{C}$ no período mais quente (MORENO, 1961).

Foi utilizado o híbrido “AG5011”, de ciclo precoce, recomendado pela empresa de sementes como híbrido para "safrinha” na Região Sul do país. A semeadura, em plantio direto, ocorreu em janeiro de 2004, com espaçamento entre linhas de $0,75 \mathrm{~m}$ e o estande final de plantas atingiu 50.000 ha-1 . A adubação de base NPK foi de $250 \mathrm{~kg} \mathrm{ha}^{-1}$ da fórmula 08-18-28, e a adubação de cobertura com uréia foi de $100 \mathrm{~kg} \mathrm{ha}^{-1}$, dividida em duas aplicações.
A colheita das plantas foi manual por meio do corte a $15 \mathrm{~cm}$ do nível do solo, em dois períodos: o primeiro no dia 26 de abril de 2004, com os grãos no estádio leitoso (GL), e o segundo em 18 de maio de 2004, quando os grãos atingiram o estádio $1 \frac{1}{2}$ leitoso $1 \frac{1}{2}$ farináceo (GF). As temperaturas-ambiente médias nos dias 26, 27 e 28 de abril de 2004 foram de $15,9^{\circ} \mathrm{C}, 18,7^{\circ} \mathrm{C}$ e $20,9^{\circ} \mathrm{C}$, respectivamente. As temperaturas médias nos dias 18,19 e 20 de maio de 2004 foram de $11,9^{\circ} \mathrm{C} ; 12,2^{\circ} \mathrm{C}$ e $12,8^{\circ} \mathrm{C}$, respectivamente, segundo dados da estação metereológica de Cruz Alta - RS, do $8^{\circ}$ Distrito de Metereologia.

Ambas as colheitas ocorreram entre as $16 \mathrm{e}$ $18 \mathrm{~h}$ do dia, sendo desprezadas as bordaduras da cabeceira $(5 \mathrm{~m})$ da lavoura de milho, e colhidos aproximadamente $1.000 \mathrm{~kg}$ de matéria verde em cada uma. A seguir, as plantas foram picadas em ensiladeira para um tamanho de corte teórico médio de 1,2cm. Para o tratamento controle, realizaram-se o enchimento e fechamento dos silos logo após a picagem das plantas. Foram utilizados minissilos constituídos por dois sacos plásticos com espessura de 12 micras cada, sobrepostos. Para facilitar a compactação, efetuou-se o pisoteio nos sacos introduzidos e armados sobre baldes plásticos com capacidade de 20 litros. Antes do fechamento dos sacos plásticos, realizou-se sucção do ar residual com aspirador de pó doméstico. Após 10 horas da vedação, os minissilos foram retirados dos baldes e armazenados em sala fechada protegida da radiação solar.

O enchimento e fechamento dos silos nos demais tratamentos ocorreram 12, 24 e 36 horas após a picagem e exposição do material ao ar, sem compactação. A ensilagem foi realizada ao anoitecer (19h) para os tratamentos zero e 24 horas e ao amanhecer (7h) para os tratamentos 12 e 36 horas de exposição ao ar antes da ensilagem.

Amostras dos materiais originais, fresco e picado, foram coletadas ( $1 \mathrm{~kg}$ de cada tratamento), acondicionadas em sacos plásticos e congeladas a $-18^{\circ} \mathrm{C}$. Dez minutos antes do enchimento dos minissilos, mediu-se a temperatura média da massa verde exposta ao ar sem compactação (Tabela 1), utilizando-se cinco termômetros de mercúrio líquido distribuídos na massa, em diferentes profundidades, nos tempos 12, 24 e 36 horas após a picagem.

$\mathrm{Na}$ abertura dos silos, desprezaram-se as camadas superiores, inferiores e laterais da silagem. Em parte da amostra retirada foi determinado, imediatamente, o teor de matéria parcialmente seca, por meio da secagem de parte do material em estufa de circulação forçada e renovação de ar a $55 \pm 0,1^{\circ} \mathrm{C}$ por 72 horas até peso constante. $\mathrm{O}$ restante da amostra foi armazenada a $-18^{\circ} \mathrm{C}$. 
Tabela 1 - Data e temperatura média do dia da confecção dos silos e temperatura média do material verde picado no momento do enchimento dos minissilos.

\begin{tabular}{|c|c|c|c|c|}
\hline \multirow{2}{*}{ Tempos } & \multicolumn{2}{|c|}{ Confecção dos minissilos } & \multicolumn{2}{|c|}{ Temperatura média $\left({ }^{\circ} \mathrm{C}\right)$} \\
\hline & Data & Horário (Horas) & do dia & da ensilagem \\
\hline \multicolumn{5}{|c|}{ Ensilagem grão completamente leitoso (GL) } \\
\hline Zero hora & $26 / 04 / 2004$ & $19: 00$ & 15,9 & ND \\
\hline 12 horas & $27 / 04 / 2004$ & 07:00 & \multirow{2}{*}{18,7} & 39,4 \\
\hline 24 horas & $27 / 04 / 2004$ & 19:00 & & 38,8 \\
\hline 36 horas & $28 / 04 / 2004$ & 07:00 & 20,9 & 41,6 \\
\hline \multicolumn{5}{|c|}{ Ensilagem grão 1⁄2 leitoso 1⁄2 farináceo (GF) } \\
\hline Zero hora & $18 / 05 / 2004$ & 19:00 & 11,9 & ND \\
\hline 12 horas & $19 / 05 / 2004$ & 07:00 & \multirow{2}{*}{12,2} & 30,4 \\
\hline 24 horas & $19 / 05 / 2004$ & 19:00 & & 37,8 \\
\hline 36 horas & $20 / 05 / 2004$ & 07:00 & 12,8 & 37,0 \\
\hline
\end{tabular}

ND = Não determinado.

* Temperatura média do dia em graus Celsius registrada na Estação Metereológica de Cruz Alta - RS. Dados fornecidos pelo $8^{\circ}$ Distrito de Metereologia.

Os teores de matéria seca (MS), proteína bruta (PB), nitrogênio insolúvel em detergente neutro (NIDN) e nitrogênio insolúvel em detergente ácido (NIDA) foram determinados segundo SILVA \& QUEIROZ (2002), após o processamento das amostras em moinho do tipo Willey adaptado com peneira de 1 milímetro.

Para as determinações de $\mathrm{pH}$ e nitrogênio amoniacal, prensou-se uma quantidade de silagem suficiente para coleta de $50 \mathrm{~mL}$ de extrato de silagem. $\mathrm{O}$ $\mathrm{pH}$ foi determinado no extrato utilizando-se potenciômetro digital e o teor de nitrogênio amoniacal foi determinado por método colorimétrico, segundo WEATHERBURN (1967).

O experimento foi realizado em delineamento completamente casualizado, em arranjo fatorial 2 x 4 (dois estádios de maturação e quatro tempos de exposição ao ar antes da ensilagem), com quatro repetições por tratamento, considerando-se os minissilos as unidades experimentais.

Os dados dos materiais originais foram submetidos somente à análise estatística descritiva e os das silagens à análise de variância por meio do software SPSS (2002), aplicando-se o teste de comparação entre médias Tukey, a 5\%, de probabilidade de erro, para as variáveis que apresentaram diferença estatística.

\section{RESULTADOS E DISCUSSÃO}

Como primeira conseqüência dos tratamentos aplicados, conforme esperado, foi constatada a elevação da temperatura do material picado e ainda não compactado exposto ao ar, o que ocorreu em níveis bem acima da temperatura ambiente, devido à respiração celular do material e à ação de microrganismos aeróbios (Tabela 1). Esta elevação de temperatura foi também pronunciada no material do segundo corte, quando a temperatura média ambiente já era tipicamente outonal, na faixa dos $12{ }^{\circ} \mathrm{C}$.

O maior teor de MS (Tabela 2) no GF era esperado, tendo-se em vista o estádio mais avançado de maturação do grão de milho, cuja diferença significativa se refletiu nas respectivas silagens. $\mathrm{O}$ conteúdo de matéria seca assume papel fundamental, aumentando a proporção de nutrientes, facilitando os processos fermentativos ou diminuindo a ação de microrganismos que afetam negativamente o valor nutricional da silagem (SENGER et al., 2004). Possivelmente, a redução na MS das silagens produzidas em relação ao material verde deve ser pela metodologia utilizada, que afeta as substâncias voláteis. Avaliando o teor de água (direto) ou MS (indireto) em 57 silagens de gramíneas, 18 silagens de leguminosas e 15 silagens mistas (gramíneas e leguminosas) por quatro métodos: extração por tolueno (ET), cromatografia gasosa (CG), Karl Fischer (KF) e secagem em estufa, PETIT et al. (1997) concluíram que o método mais promissor é o KF, visto que a secagem em estufa elimina os constituintes voláteis, o tolueno é cancerígeno e a técnica por CG ainda é financeiramente inviável. Apesar da secagem em estufa subestimar o teor de MS, esse ainda é o método mais utilizado nos laboratórios de países em desenvolvimento, como o Brasil, devido ao baixo custo.

Apesar da maior variação no aquecimento da massa verde (Tabela 1) no GF em relação à temperatura ambiente, o material ensilado após 36 horas de exposição ao ar ainda apresentava condições mais

Ciência Rural, v.38, n.1, jan-fev, 2008. 
Tabela 2 - Valores médios de pH e teores médios de matéria seca, proteína bruta, nitrogênio amoniacal, nitrogênio insolúvel em detergente neutro e nitrogênio insolúvel em detergente ácido dos materiais originais e das silagens.

\begin{tabular}{|c|c|c|c|c|c|c|}
\hline \multirow{2}{*}{ Períodos ${ }^{1}$} & \multicolumn{3}{|c|}{ Material original } & \multicolumn{3}{|c|}{ Silagens } \\
\hline & $\mathrm{GL}^{2}$ & $\mathrm{GF}^{3}$ & Média & $\mathrm{GL}^{2}$ & $\mathrm{GF}^{3}$ & Média $^{4}$ \\
\hline \multicolumn{7}{|c|}{$\mathrm{pH}$} \\
\hline Zero hora & 5,48 & 5,62 & 5,55 & 3,63Аа & 3,77Bb & 3,70 \\
\hline 12 horas & 5,02 & 5,14 & 5,08 & 3,64Aa & $3,78 \mathrm{Bb}$ & 3,71 \\
\hline 24 horas & 4,52 & 4,62 & 4,57 & $3,81 \mathrm{Ba}$ & $3,74 \mathrm{Ab}$ & 3,78 \\
\hline 36 horas & 4,54 & 4,76 & 4,65 & $4,00 \mathrm{Ca}$ & $3,90 \mathrm{Cb}$ & 3,95 \\
\hline Média $^{4}$ & 4,89 & 5,04 & 4,97 & 3,77 & 3,80 & 3,78 \\
\hline $\mathrm{DP}^{5}$ & 0,46 & 0,45 & 0,43 & 0,02 & 0,01 & 0,01 \\
\hline \multicolumn{7}{|c|}{ Matéria seca (\%) } \\
\hline Zero hora & 23,3 & 30,8 & 27,0 & 22,0 & 27,9 & $25,0 \mathrm{~A}$ \\
\hline 12 horas & 22,1 & 29,0 & 25,5 & 20,9 & 26,5 & $23,7 \mathrm{C}$ \\
\hline 24 horas & 23,0 & 28,4 & 25,7 & 20,8 & 27,9 & $24,3 \mathrm{BC}$ \\
\hline 36 horas & 23,0 & 27,7 & 25,4 & 21,6 & 28,4 & $25,0 \mathrm{~A}$ \\
\hline Média $^{4}$ & 22,8 & 29,0 & 25,9 & $21,3 b$ & $27,7 \mathrm{a}$ & 24,5 \\
\hline $\mathrm{DP}^{5}$ & 0,52 & 1,35 & 3,41 & 0,64 & 1,12 & 3,36 \\
\hline \multicolumn{7}{|c|}{ Proteína bruta (\% da MS) } \\
\hline Zero hora & 8,2 & 7,5 & 7,9 & 8,4 & 8,0 & $8,2 \mathrm{~B}$ \\
\hline 12 horas & 7,8 & 7,9 & 7,8 & 9,0 & 7,9 & $8,5 \mathrm{AB}$ \\
\hline 24 horas & 7,4 & 7,6 & 7,5 & 8,5 & 8,1 & $8,3 \mathrm{AB}$ \\
\hline 36 horas & 9,0 & 7,6 & 8,3 & 9,6 & 8,1 & $8,9 \mathrm{~A}$ \\
\hline Média $^{4}$ & 8,1 & 7,7 & 7,9 & $8,9 a$ & $8,0 \mathrm{~b}$ & 8,5 \\
\hline $\mathrm{DP}^{5}$ & 0,66 & 0,16 & 0,50 & 0,50 & 0,50 & 0,68 \\
\hline \multicolumn{7}{|c|}{ Nitrogênio amoniacal (\% do NT) } \\
\hline Zero hora & 4,1 & 2,3 & 3,2 & $6,1 \mathrm{Ab}$ & 4,3Аа & 5,2 \\
\hline 12 horas & 3,9 & 1,4 & 2,7 & $5,6 \mathrm{Ab}$ & 4,4Aa & 5,0 \\
\hline 24 horas & 4,2 & 2,1 & 3,1 & $7,4 \mathrm{Bb}$ & 4,2Аa & 5,8 \\
\hline 36 horas & 2,8 & 2,1 & 2,4 & $6,9 \mathrm{Bb}$ & 4,4Aa & 5,7 \\
\hline Média $^{4}$ & 3,8 & 2,0 & 2,9 & 6,5 & 4,3 & 5,4 \\
\hline $\mathrm{DP}^{5}$ & 0,64 & 0,38 & 1,08 & 1,08 & 0,32 & 1,33 \\
\hline \multicolumn{7}{|c|}{ Nitrogênio insolúvel em detergente neutro (\% do NT) } \\
\hline Zero hora & 36,0 & 24,5 & 30,2 & 31,1 & 14,4 & $22,7 \mathrm{~A}$ \\
\hline 12 horas & 40,2 & 28,7 & 34,5 & 32,2 & 17,7 & $25,0 \mathrm{AB}$ \\
\hline 24 horas & 39,7 & 36,2 & 37,9 & 34,1 & 28,1 & $31,1 \mathrm{BC}$ \\
\hline 36 horas & 46,5 & 40,6 & 43,5 & 38,7 & 30,3 & $34,5 \mathrm{C}$ \\
\hline Média $^{4}$ & 40,6 & 32,5 & 36,6 & $34,0 \mathrm{~b}$ & $22,6 a$ & 28,3 \\
\hline $\mathrm{DP}^{5}$ & 4,36 & 7,24 & 7,03 & 6,49 & 7,48 & 8,91 \\
\hline \multicolumn{7}{|c|}{ Nitrogênio insolúvel em detergente ácido (\% do NT) } \\
\hline Zero hora & 12,6 & 9,1 & 10,8 & 11,8Аa & $12,9 \mathrm{Ba}$ & 12,4 \\
\hline 12 horas & 12,1 & 9,7 & 10,9 & 9,9Аа & $11,8 \mathrm{Ba}$ & 10,9 \\
\hline 24 horas & 6,9 & 8,9 & 7,9 & $10,7 \mathrm{Aa}$ & $12,1 \mathrm{Ba}$ & 11,4 \\
\hline 36 horas & 11,4 & 14,5 & 13,0 & 8,3Аа & $16,3 \mathrm{Bb}$ & 12,3 \\
\hline Média $^{4}$ & 10,7 & 10,6 & 10,7 & 10,2 & 13,3 & 11,7 \\
\hline $\mathrm{DP}^{5}$ & 2,62 & 2,67 & 2,45 & 1,94 & 2,68 & 2,75 \\
\hline
\end{tabular}

1 - Tempo de exposição ao ar antes da ensilagem; 2 - Grão completamente leitoso; 3 - Grão 1⁄2 leitoso 1⁄2 farináceo; 4 - Médias seguidas por letras diferentes, minúsculas na coluna e maiúsculas na linha, são estatisticamente diferentes a $5 \%$ de probabilidade de erro. 5 - Desvio padrão.

adequadas para ensilagem, em relação ao material do GL. Os valores de $\mathrm{pH}$ (Tabela 2) indicam que a oxidação aeróbia foi mais intensa no material leitoso do que no $1 / 2$ leitoso $1 \frac{1}{2}$ farináceo, provavelmente em função dos maiores teores médios de açúcares solúveis, que foram de 11,66 e 9,37\% da MS, para os materiais originais do GL e GF, respectivamente, como apresentado por VELHO et al. (2006).

Ciência Rural, v.38, n.1, jan-fev, 2008. 
Os diferentes valores numéricos de $\mathrm{pH}$ para as amostras de material original de ambos os estádios de maturidade (Tabela 2), provavelmente, são reflexos das distintas proporções iniciais (tempo zero), intermediárias (12 e 24 horas) e finais (36 horas) do teor de açúcares solúveis no momento da ensilagem, fração glicídica esta que geralmente é consumida pela continuada respiração das plantas ou exaurida por microorganismos aeróbios. A respiração das plantas após o corte, portanto em déficit fotossintético, causa perdas de matéria seca e de carboidratos rapidamente fermentáveis, representando perdas energéticas nas plantas colhidas, além de menor quantidade de substrato para os lactobacilos, diminuindo o valor nutricional da silagem produzida (MUCK, 1988).

Os valores de $\mathrm{pH}$ dos materiais originais (Tabela 2) são inferiores aos valores obtidos por MUCK (2004) de 5,90; 5,98 e 5,79, respectivamente para plantas de milho colhidas nos anos de 1999, 2000 e 2001, e superiores ao valor obtido por RANJIT \& KUNG Jr. (2000) de 5,44 para plantas de milho colhidas com 31,3\% de MS.

Na tabela 2, é apresentada a interação entre os fatores estádio de maturação do grão e tempo de exposição ao ar antes da ensilagem, em relação aos valores de $\mathrm{pH}$, sendo que no GL a amplitude de variação foi superior a do GF, confirmando que plantas em estádio mais adequado de ensilagem, com maior teor de carboidratos não-estruturais, sofrem proporcionalmente menos, até que os efeitos maléficos da respiração celular sejam paralisados. Estudando o efeito da umidade e compactação sobre o valor nutricional de silagens de milho de planta inteira, SENGER et al. (2005) demonstraram que o teor de MS não apresentou efeito sobre o $\mathrm{pH}$, o que não ocorreu com o efeito compactação dentro dos distintos teores de MS (20; 26 e 28,0\%), que diferiram estatisticamente.

Avaliando silagens de milho nos estádios de maturidade no início da formação do grão (20\% de MS), leitoso (26\% de MS) e $1 \frac{1}{2}$ leitoso $1 / 2$ farináceo na região da Província de Buenos Aires, Argentina, DI MARCO et al. (2002) verificaram respectivamente $\mathrm{pH}$ de 3,4; 3,6 e 3,7, cujos valores são semelhantes aos obtidos neste estudo (Tabela 2) para as silagens do GL e GF no tempo zero.

Verifica-se, na tabela 2, que, em relação ao tratamento controle, o período de 36 horas de aerobiose antes da ensilagem aumentou o teor médio de PB das silagens, o que pode ser explicado pela oxidação dos CHO solúveis e proporcional aumento do $\mathrm{N}$ total.

Os valores de PB do material original de ambos os estádios de maturidade (Tabela 2) são inferiores aos valores médios obtidos por RODRIGUES et al. (2004) para as plantas de milho dos híbridos “AG510” (8,48\% de PB na MS) e “AG5011” (9,99\% de PB na MS) e semelhantes aos valores obtidos por SILVA et al. (2005) de 7,68\% de PB na MS para o híbrido “AG1051", em cujos trabalhos as plantas foram colhidas quando o grão atingiu o estádio farináceo duro.

A silagem de milho é uma excelente fonte de energia para a alimentação do gado de leite, porém é considerada como alimento não-completo por possuir baixo teor de proteína (ZANINI et al., 2003). Os baixos teores de $\mathrm{PB}$ na silagem de milho próximos ao teor de $7 \%$ de PB na MS aceito como limitante do crescimento microbiano para potencializar a fermentação ruminal, em geral, são ocasionados pelo fato de as plantas de milho serem cultivadas nas piores glebas de terra da propriedade rural, sem investimentos específicos. No entanto, quando o cultivo do milho é destinado à produção de silagem de qualidade, portanto, necessitando de área fértil e com adequada adubação de base e nitrogenada, frequentemente, apresentam teores próximos dos 10\% de PB na MS.

Os valores de PB das silagens (Tabela 2) são maiores do que os valores obtidos por ROCHA Jr. et al. (2003), de 7,25\% de PB na MS, por COSTA et al. (2005), de 5,6\% de PB na MS, e por SILVA et al. (2005), de 7,68\% de PB na MS para silagens de milho. Avaliando a adição de inoculantes a silagens de milho com teores médios de MS de 35,26\% e 44,06\%, RODRIGUES et al. (2004) obtiveram aumentos nas quantidades de PB de $8,07 \%$ para $9,73 \%$.

Os valores de $\mathrm{N}-\mathrm{NH}_{3}$ dos materiais originais (Tabela 2) são consideravelmente superiores aos tabelados por GIVENS \& RULQUIN (2004) de 0,9\% do NT para plantas de milho com 10,4\% de PB. Porém, os valores nas silagens são inferiores aos tabelados pelos mesmos autores de 7,1\% do NT com 8,4\% da PB. Devido à interação entre os fatores principais maturidade e tempo de exposição (Tabela 2), a silagem GL produziu $15 \%$ a mais de $\mathrm{N}-\mathrm{NH}_{3}$ do que a silagem do GF, partindo de diferentes valores de $\mathrm{N}-\mathrm{NH}_{3}$ dos materiais verdes, possivelmente por condições mais adequadas (alta temperatura e umidade) para o desenvolvimento de microorganismos que degradam a proteína, bem como aumentam a ação catalítica das enzimas das plantas. A cada aumento de $10^{\circ} \mathrm{C}$, todas as reações químicas aproximadamente duplicam as suas taxas (VAN SOEST, 1994).

Os valores de $\mathrm{N}-\mathrm{NH}_{3}$ em relação ao NT são considerados baixos, em média 5,4\% (Tabela 2), indicando que, sob esse aspecto, a fermentação foi adequada, sendo valores próximos aos obtidos por SENGER et al. (2005) para silagens bem compactadas, com $28 \%$ de MS (5,27\% do NT), e inferiores aos com 26 e $20 \%$ de MS (6,50 e 7,48\% do NT). 
O prolongamento do tempo de exposição ao ar antes da ensilagem resultou em aumento $(\mathrm{P}<0,05)$ gradativo do valor médio da fração NIDN das silagens (Tabela 2). Essa fração provavelmente aumentou devido ao incremento da temperatura da massa (Tabela 1), o que se reflete na diminuição de sua solubilidade.

Os estádios de maturidade apresentaram diferença estatística para o teor de NIDN (Tabela 2), sendo favorável ao GF, como era esperado pelo maior teor de MS (Tabela 2), o qual foi 11,42 unidades percentuais inferior ao GL. Tabelando dados de silagem de milho com $31,4 \%$ de MS e 7,1\% de PB na MS nas condições brasileiras, TEDESCHI et al. (2002) reportaram teores de $14,6 \%$ de NIDN do NT, cujos valores são semelhantes aos obtidos neste estudo para GF no tempo zero.

O teor de NIDN (Tabela 2) sofreu efeito a partir das 24 horas de exposição ao ar antes da ensilagem. Com 24 e 36 horas de exposição, o NIDN incrementou, respectivamente, em 36,83 e 51,78\% em relação à silagem do tempo zero. Independentemente do teor inicial de NT na silagem de milho, aumentos destas magnitudes são inapropriados, visto que diminuem a degradabilidade da fração protéica, que geralmente é deficitária em silagens de milho, além de possivelmente diminuir também a digestibilidade intestinal devido ao aquecimento ocorrido na exposição da ensilagem ao ar (Tabela 1). A fração protéica $\mathrm{B}_{3}$ do CNCPSv5.0 que é mensurada subtraindo o NIDN do NIDA contém tipicamente proteínas do tipo prolamina e extensina, praticamente indegradáveis no rúmen e com digestibilidade intestinal de $80 \%$ (FOX et al., 2003). O CNCPS considera digestibilidades verdadeiras de $100,100,80$ e $0 \%$ para as frações nitrogenadas $B_{1}, B_{2}$, $\mathrm{B}_{3}$ e $\mathrm{C}$ (SNIFFEN et al., 1992). O rúmen geralmente funciona como um sistema limitado pela energia no entanto, dietas com baixa quantidade de proteína degradável podem limitar o crescimento microbiano, sendo que as bactérias respondem diferentemente à fonte e à limitação de nitrogênio (TEDESCHI et al., 2000).

Conduzindo experimento em arranjo fatorial $2 \times 3$ (dois processamentos na ensilagem e três tamanhos de picado), JOHNSON et al. (2003) obtiveram em média $16 \%$ de NIDN do NT, valor próximo ao verificado neste experimento (Tabela 2) para a silagem do GF no tempo zero, concordando também com os valores tabelados por SNIFFEN et al. (1992) de 16\% de NIDN do NT para silagens de milho produzidas nos EUA.

Após 36 horas de aerobiose, na silagem de GF, com maior teor de MS (Tabela 2), o aquecimento causado pela aerobiose (Tabela 1) resultou num aumento significativo do NIDA (Tabela 2), que é indigestível ao ruminante, contudo de diferentes magnitudes entre os estádios de maturidade. A fração C do CNCPSv5.0 que é representada pelo teor de NIDA possui degradabilidade e digestibilidade nulas (FOX et al., 2003). Porém, WEISS et al. (1992) consideram que o NIDA apresenta digestibilidade de $30 \%$.

Os valores de NIDA encontrados na literatura nacional para silagem de milho divergem consideravelmente. Verificando-se valores tão baixos como os reportados por ROCHA Jr et al. (2003), de $7,17 \%$ de NIDA do NT (7,25\% de PB), e por COSTA et al. (2005), de 5,76\% de NIDA do NT (PB 5,6\% da MS), bem como os elevados valores apresentados por ZEOULA et al. (2003) para lâmina foliar de plantas de milho com teores extremos entre 47,78 e $30,06 \%$ de NIDA do NT, respectivamente com teores de PB de 11,41 e $11,68 \%$.

As simulações de mau manejo de ensilagem, com tempos de até $36 \mathrm{~h}$ de exposição ao ar, com pequenas quantidades de silagem (11,1kg de matéria verde) e em condições ambientais relativamente controladas, geraram diferenças significativas na maior parte das frações nitrogenadas, inclusive com interação entre os fatores principais (estádio de maturidade $\mathrm{x}$ tempo de exposição ao ar), o que, extrapolado para as condições de campo, resultaria em efeitos mais significativos, quando o manejo de ensilagem for inapropriado. Entretanto, deve-se ter o cuidado para inferir dados obtidos em silos experimentais para uma escala comercial (RIBEIRO et al., 2005).

\section{CONCLUSÕES}

A interação entre os fatores estádio de maturidade e tempos de exposição ao ar aumentam o valor médio de $\mathrm{pH}$ das silagens produzidas, porém com diferentes magnitudes.

O manejo inadequado na ensilagem decorrente da demora no enchimento do silo aumenta a fração nitrogenada insolúvel, ou seja, diminui a degradabilidade protéica e afeta negativamente a digestibilidade e o valor nutritivo da silagem. Silagens de milho colhidas com grão leitoso comprometem a palatabilidade pelo maior teor de nitrogênio amoniacal.

\section{AGRADECIMENTOS}

Ao Conselho Nacional de Desenvolvimento Científico e Tecnológico (CNPq), pela Bolsa de Mestrado do autor J.P. Velho e de Produtividade em Pesquisa do autor P.R.F. Mühlbach.

\section{REFERÊNCIAS}

BERTO, J.L. et al. Qualidade da silagem de milho em unidades de produção de leite no Rio Grande do Sul. In: REUNIÃO 
ANUAL DA SOCIEDADE BRASILEIRA DE ZOOTECNIA, 35., 1998, Botucatu. SP. Anais... Botucatu: SBZ, 1998. (CDROM).

COSTA, M.A.L. et al. Validação das equações do NRC (2001) para predição do valor energético de alimentos nas condições brasileiras. Revista Brasileira de Zootecnia, v.34, n.1, p.280287, 2005.

DI MARCO, O.N. et al. Effect of maize crop maturity on silage chemical composition and digestibility (in vivo, in situ and in vitro). Animal Feed Science and Technology, v.99, n.1, p.37-43, 2002.

FOX, D.G. et al. The net carbohydrate and protein system for evaluating herd nutrition and nutrient excretion. Ithaca: Department of Animal Science, Cornell University, 2003. 292p.

GIVENS, D.I.; RULQUIN, H. Utilization by ruminants of nitrogen compounds in silage-based diets. Animal Feed Science and Technology, v.114, p.1-18, 2004.

JOBIM, C.C. et al. Sistemas de produção de leite com ênfase na utilização de volumosos conservados. In: REIS, R.A. et al. (Eds.). Volumosos na produção de ruminantes. Jaboticabal: Funep, 2005. p.61-82.

JOHNSON, L.M. et al. Corn silage management: effects of hybrid, chop length, and mechanical processing on digestion and energy content. Journal of Dairy Science, v.86, n.1, p.208-231, 2003.

MOREnO, J.A. Clima do Rio Grande do Sul. Porto Alegre: Secretaria da Agricultura, 1961. 41p.

MUCK, R.E. Effects of corn silage inoculants on aerobic stability. Transactions of the ASAE, v.47, p.1011-1016, 2004.

MUCK, R.E. Factors influencing silage quality and their implications for management. Journal of Dairy Science, v.71, n.11, p.2992-3002, 1988.

PETIT, H.V. et al. A comparison oh methods to determine dry matter in silages. Journal of Dairy Science, v.80, n.3, p.558562, 1997.

RANJIT, N.K.; KUNG Jr., L. The effect of Lactobacillus buchneri, Lactobacillus plantarum, or a chemical preservative on the fermentation and aerobic stability of corn silage. Journal of Dairy Science, v.83, n.3, p.526-535, 2000.

RESENDE, F.D. et al. Terminação de bovinos de corte com ênfase na utilização de volumosos conservados. In: REIS, R.A. et al. (Eds.) Volumosos na produção de ruminantes. Jaboticabal: Funep, 2005. p.83-106.

RIBEIRO, J.L. et al. Desenvolvimento de aditivos microbianos para ensilagem: realidade e perspectivas. In: REIS, R.A. et al. (Eds.). Volumosos na produção de ruminantes. Jaboticabal: Funep, 2005. p.1-23.

ROCHA Jr., V.R. et al. Determinação do valor energético de alimentos para ruminantes pelo sistema de equações. Revista Brasileira de Zootecnia, v.32, n.2, p.473-479, 2003.

RODRIGUES, P.H.M. et al. Avaliação do uso de inoculantes microbianos sobre a qualidade fermentativa e nutricional da silagem de milho. Revista Brasileira de Zootecnia, v.33, n.3, p.538-545, 2004.

ROTZ, C.A.; MUCK, R.E. Changes in forage quality during harvest and storage. In: FAHEY Jr., G.C. et al. (Eds.). National conference on forage quality, evaluation, and utilization. Madison: University of Nebraska, 1994. p.828-868.

SENGER, C.C.D. et al. Composição e digestibilidade 'in vitro' de silagens de milho com distintos teores de umidade e níveis de compactação. Ciência Rural, v.35, n.6, p.1393-1399, 2005.

SENGER, C.C.D. et al. Influência da umidade e compactação sobre os carboidratos estruturais e glicídios solúveis de silagens de milho. In: REUNIÃO ANUAL DA SOCIEDADE BRASILEIRA DE ZOOTECNIA, 41., 2004, Campo Grande, MS. Anais... Campo Grande: SBZ, 2004. (CD-ROM).

SILVA, A.V. et al. Composição bromatológica e digestibilidade in vitro da matéria seca de silagens de milho e sorgo tratadas com inoculantes microbianos. Revista Brasileira de Zootecnia, v.34, n.6, p.1881-1890, 2005.

SILVA, D.J.; QUEIROZ, A.C. de. Análise de alimentos métodos químicos e biológicos. Viçosa: UFV, 2002. 235p.

SNIFFEN, C.J. et al. A net carbohydrate and protein system for evaluating cattle diets: II. Carbohydrate and protein availability. Journal Animal Science, v.70, n.11, p.3562-3577, 1992.

SPSS. User's guide: Statistics. SPSS Inc Version 11.5 Headquarters, Chicago, IL, 2002. 1 CD.

TEDESCHI, L.O. et al. Development and evaluation of tropical feed library for The Cornell Net Carbohydrate and Protein System Model. Scientia Agricola, v.59, n.1, p.1-18, 2002.

TEDESCHI, L.O. et al. Accounting for the effects of a ruminal nitrogen deficiency within the structure of the Cornell net carbohydrate and protein system. Journal of Animal Science, v.78, n.6, p.1648-1658, 2000.

VAN SOEST, P.J. Nutritional ecology of the ruminant. Ithaca: Cornell University, 1994. 476p.

VELHO, J.P. et al. Alterações bromatológicas nas frações dos carboidratos de silagens de milho "safrinha" sob diferentes tempos de exposição ao ar antes da ensilagem. Revista Brasileira de Zootecnia, v.35, n.4, p.1621-1628, 2006. Suplemento.

WEATHERBURN, M.W. Phenol-hypochlorite reaction for determination of ammonia. Analytical Chemistry, v.39, p.971-974, 1967.

WEISS, W.P. et al. A theoretically-based model for predicting total digestible nutrient values of forages and concentrates. Animal Feed Science and Technology, v.39, p.95-110, 1992.

ZANINI, A. et al. Análise do consumo de energia na produção de silagem de milho em plantio direto. Acta Scientiarum Animal Sciences, v.25, n.2, p.249-253, 2003.

ZEOULA, L.M. et al. Avaliação de cinco híbridos de milho (Zea mays, L.) em diferentes estádios de maturação. 3. Composição químico-bromatológica. Revista Brasileira de Zootecnia, v.32, n.3, p.556-566, 2003. 